\title{
Critical Review on Hotel Tax over Boarding House from the Perspective of Islamic Equality Principle
}

\author{
Khoirul Hidayah \\ (UIN Maulana Malik Ibrahim Malang Jalan Gajayana No. 50 Malang \\ Email:khoirulhidayah55@gmail.com)
}

\begin{abstract}
Abstrak:
Pemungutan pajak hotel atas rumah kos dengan jumlah kamar lebih dari 10 (sepuluh) menimbulkan kekaburan makna antara hotel dan rumah kos. Pemungutan tersebut dirasakan oleh masyarakat tidak memenuhi rasa keadilan. Beberapa persoalannya adalah hal mendasar terkait perbedaan antara hotel dan kos. Pertama, apakah makna "pelayanan yang disediakan rumah kos" dapat ditafsirkan sama dengan "pelayanan yang disediakan hotel". Kedua, bagaimanakah pengaturan pajak hotel atas rumah kos yang terdapat di dalam Undang Undang No. 28 Tahun 2009 Tentang Pajak Daerah dan Retribusi Daerah bila ditinjau dari prinsip keadilan. Makna sebenarnya atas pelayanan hotel dan pelayanan rumah kos adalah berbeda dan pengaturan pajak hotel atas rumah kos belum bahkan tidak memenuhi prinsip keadilan. Tulisan ini merupakan hasil penelitian normatif. Analisis yang digunakan adalah metode interpretasi modern dan teori keadilan.
\end{abstract}

\section{Kata-kata Kunci:}

Pajak Hotel, Rumah Kos, Keadilan, Pelayanan hotel

\begin{abstract}
:
Hotel tax over boarding house with more than ten rooms blurs the meaning of hotel and boarding house and hurts social equality. The first problem deals with the question whether the meaning of "service provided by boarding house" has the same meaning with "service provided by hotel". The second one deals with how the regulation on hotel tax over boarding house stated in Law number 28 of 2009 concerning Local Taxation and Charges is from the perspective of equality. The study employs a normative research using modern interpretation method analysis and equality theory. Hotel service is different from boarding
\end{abstract}


Khoirul Hidayah

house service. Therefore, the regulation concerning hotel tax over boarding house is considered unfair.

Key Words:

Hotel Tax, Boarding House, Equality, Hotel Service

\section{Introduction}

To develop local region, it is important to encourage local society to share the cost. In order to realize the effort, the local government is given the authority to charge local tax (city or residence). The government has done several amendment on local taxation and charges. The recent one is Law number 28 of 2009 concerning Local Taxation and Charges.

The law regulates some local taxes such as hotel tax. Rapid growth of boarding house as a business leads the government to make it as an object of local tax. According to the law, boarding houses have to pay hotel tax. Article 1 of the law mentions that hotel includes boarding house with more than ten rooms. The government uses it as a basis to make the business as a source of local revenue. However, in the practice the government faces some problems dealing with the application of the hotel tax over boarding house. It may lead society to think that the regulation is not fair. Furthermore, in reality, the condition of the boarding house itself varies, from the simple to luxurious ones. If it is measured from the total rooms, which is ten rooms, then it will be unclear. It also leads to a question whether the regulation will be applied to both simple and luxurious boarding houses. Some people may think that the tax is paid by the owner, so the owner has to pay double tax. The first is income tax, based on Law number 36 of 2008 concerning Income tax, article 4 paragraph 2 on income from land and or building rent. The second one is hotel tax based on article 32 of Law number 28 of 2009 concerning Local Taxation and Charges. Since the tax objects are different, the concept of double tax does not exist. Such wrong perception in society may confuse the owners and makes them refuse to pay the tax.

The interpretation difference on the hotel tax application over boarding houses by local government brings some facts such as a policy of Kupang City government in 2015 applying the hotel tax over boarding house but it is not based on the ten total room as stated by 
the law. It considered that the regulation is not fair so it applied the same regulation for all boardinghouse owners, regardless the total room they have. For the government, it is not fair that luxurious boarding house with ten rooms do not have to pay tax, while the simple ones with more than ten rooms have to pay hotel tax. ${ }^{1}$

Surabaya local government also faces some problems regarding the tax application. The head of local people representative, Mochamad Machmud, said that the regulation of total room has been used by the owners to avoid the tax. They tend to build their boarding houses with no more than ten rooms but with millions rate. ${ }^{2}$ The fact of daily basis boarding houses in Surabaya City is an interesting phenomenon. The head of Local Revenue Office and Financial Management of Surabaya City, Suhartojo faces difficulty since the fact shows the phenomena of daily basis boarding house with expensive rate and luxurious facilities. The owners have been used boarding house tax, which is only $5 \%$, rather than hotel tax, which is $10 \%$ (Local regulation number 4 of 2011 concerning Local Tax). Similar facts are found in Malang City. Based on the observation, Malang has numerous daily basis boarding houses in order to avoid hotel tax. The owner prefers to pay cheaper boarding house tax (hotel tax $10 \%$, boarding house tax 5\% based on Local Regulation number 16 of 2010 concerning Local Tax).

Based on the explanation, the concept of boarding house tax as mentioned in the law of Local Taxation and Charges has been differently accepted by the society and local government as the policy maker. Therefore, it tends to create multi interpretation. Some people may differentiate hotel and boarding house. The uncertainty of boarding house tax concept in the law makes the researcher to review the law to find the real meaning of hotel tax over boarding house and study the regulation of boarding house tax from the equality perspective.

Some researchers have conducted studies on hotel tax over boarding house from the perspective of law, economics, and administration. All of them employ empirical studies, for example

\footnotetext{
1 NTT Online. Kupang. Boarding House Tax is no Longer Based on the Total Room Pajak Kos-kosan.. March 5, 2015

2 Surya Online, Saturday, June 15, 2013
} 
Lisa et al. on the potency of hotel tax in Surabaya ${ }^{3}$, Mewah on hotel tax in Manado4, Niken on boarding house tax practice in Malang City ${ }^{5}$, Williantino on boarding house tax practice in Banyuwangi ${ }^{6}$ and Anjani on the social perception concerning boarding house tax stated in local regulation. ${ }^{7}$ The result of previous studies tend to review it from an empirical perspective. No studies have been done from the equality perspective. It is interesting to study hotel tax over boarding house as stated in the law of Local Taxation and Charges from the equality perspective since the law has been made as basic norm for local tax managed with local regulation.

\section{Research Method}

The researcher employs a juridical normative study, statute and conceptual approach. The statute approach deals with hotel tax over boarding house as stated in the law number 28 of 2009 concerning Local Taxation and Charges. Meanwhile, conceptual approach deals with the concept of hotel tax over boarding house using equality theory.

Firstly, the analysis will list laws regarding boarding house tax. Then, the next step is to interpret the object of hotel tax over boarding house using modern interpretation of Ian McLeod ${ }^{8}$. The last is to systemize and study the regulation of hotel tax over boarding house using the theory of justice by John Rawls and equality theory by Aristotle.

\footnotetext{
${ }^{3}$ Lisa Hendra Jaya, Retnaningtyas Widuri. The Analysis of Hotel Tax Potency toward Tax Revenue Realization from Star Hotels in Surabaya. Tax And Accounting Review. Vol. 1 No. 1 (2013)

4 Ew. Mewah. Hotel and Restaurant Effectiveness and Contribution toward Local Revenue of Manado City. Jurnal Riset Ekonomi, Manajemen, Bisnis. December 2013.

${ }^{5}$ Niken Wulandari The Analysis of Taxpayer Compliment toward Local regulation of Malang City number 16 of 2010 concerning Boarding House Tax. Jurnal Mahasiswa Perpajakan. Vol 7, No 1 (2015)

6 A Williantino. The Role of Banyuwangi Local Revenue Office in Optimizing the Revenue from the Boarding Houses with more than ten rooms. Jurnal Mahasiswa Fakultas Hukum, February 2015

7 Anjani Dwi Swastika, Devi Pusposari.The Perception of Boarding House Owners on the Local Regulation of Malang City number 16 of 2010 concerning Local Tax. Jurnal Ilmiah Mahasiswa FEB. Vol 2, No 2 (2013)

8 Ian McLeod. Legal Methode. Macmillan. London 1999. 281 (Cited from Peter Mahmud. Legal Research. Jakarta: Prenada Media. 2005. 115)
} 


\section{The Findings and Analysis}

\section{The Real Meaning of 'Hotel Services'}

The regulation of hotel tax over boarding house as stated in article 1 of law of Local Taxation and Charges still has an uncertain meaning. It is shown in the definition of boarding house with more than ten rooms which is considered equal to hotel. It is interesting to study further on the definition. Some local regulations have different interpretation regarding the equality on the article of the law.

The article 32 (1) of Law of Local Taxation and Charges UU PDRD mentions that the object of Hotel Tax is the "services provided by Hotels" with payment, including support services as supplementary to Hotels with the characteristics of providing ease and comfort, including sports and entertainment facilities ${ }^{9}$. It is important to first explain the real meaning of hotel in order to explain further whether hotel services are equal to boarding house services.

To help finding the real meaning of hotel, the researcher employs an interpretation method. Law interpretation method can be used for the existing regulation even though it is unable to provide a real meaning when it is applied. This method consists of some types such as grammatical, historical, systematic, sociological / teleological, comparative, futuristic, restrictive, extensive, authentic, interdisciplinary and multidisciplinary interpretation. ${ }^{10}$

Based on its development, Ian McLeod tried to develop a new interpretation model by combining some interpretations. He called it as modern interpretation ${ }^{11}$. According to McLeod, modern

\footnotetext{
9 Article 32 (1) of Law number 28 of 2009 concerning Local Taxation and Charges. Paragraph 2 explains that support services as referred in paragraph 1 are constitute facilities for telephone, facsimile, telex, Internet, photocopy, laundry and ironing, transportation, and other similar facilities provided or managed by Hotels. Paragraph 3 explain that excluded from objects of Hotel Tax as referred to paragraph (1) are: a. dormitory accommodation services carried out by the Government or Regional Government; b. Rental services of apartments, condominiums, and the like; c. accommodation services at education or religious activities centers; $d$. accommodation services at hospitals, nurse dormitories, old folks' homes, orphanages and other social homes of the like; and e. services of travel bureaus or tour travel carried out by Hotels that can be used by the public.

10 Jazim Hamidi, Legal Hermeneutics. Yogjakarta: UII press. 2005. 53-57

11 Decision on Hoge Raad in 1921 concerning theft of electricity by some criminal law writers such as Moeljatno is considered as extentive interpretation.
} 
interpretation emphasizes on the word meaning in the place where it is used ${ }^{12}$. Therefore, the most important thing in performing modern interpretation is the ability to identify the elements of the context. McLeod discusses two main ideas on modern interpretation, language and law. ${ }^{13}$

Furthermore, according to Mcleod, understanding a meaning of a legal text cannot be only done from its language or grammatical interpretation, which often refers to the KBBI or Great Dictionary of the Indonesian Language (Black's Law), but also from the meaning of the law itself (it can be seen from the 'preambles' or the basis of law regulation consideration) or from its interpretation. It aims to get a comprehensive meaning on the objective of the law.

In order to get the real meaning of the hotel, the analysis of the study will employ modern interpretation (a model by Ian Mcleod). This interpretation will use two ideas. The first is language referring to Indonesian standard language dictionary and the daily common language used by the society. The second study is about law of real interpretation of hotel by law.

\section{Interpretation of Language Approach}

The interpretation of language approach will refer to the KBBI (Great Dictionary of the Indonesian Language) as guidance of Indonesian Language use, Wikipedia as encyclopedia which is widely used as reference of electronic media, and language prevalence used by people. Law of Local Taxation and Charges has stated the meaning of hotel in article 1 :

Hotel is a provider of facility in accommodation including other related services with fees, it includes motel, inn, tourist hut, home-stay, guest-house, accommodation, and etc, also boarding house of room more than ten. ${ }^{14}$

The meaning of hotel refers to law makes boarding house with rooms more than 10 is included into hotel. Law gives extension for the interpretation of hotel. It is interesting to know first the meaning of some accommodations stated in article 1 . There are several kinds of accommodations stated in the interpretation of hotel in Law of Local

\footnotetext{
12 Ian McLeod, Legal Method. Macmillan. London.1999. 281

13 Peter Mahmud. Op.cit. 115

${ }^{14}$ Article 1 number 21 UU No. 28 in 2009 about Regional Tax and Charges
} 
Taxation and Charges according to the Great Dictionary of the Indonesian Language ${ }^{15}$, Wikipedia and language prevalence which is used by people:

\section{The Term of Hotel}

According to Wikipedia, the word hotel comes from word hostel (classic France). Great Dictionary of the Indonesian Language gives definition as follow:

Hotel is a building with many rooms which is rented as accommodation and restaurant for the people on the trip. The accommodation form is managed commercially. Available for every people to get service, accommodation, food and beverage. ${ }^{16}$

That interpretation states that hotel is a place to stay for people on the trip, it is accidental, not for basic needs. According to the social perspective, people who go to the hotel are rich people because it is considered as secondary need and they will get services.

\section{The Term of Motel}

According to Wikipedia ${ }^{17}$ motel is an abbreviation of English words motorist hotel; which means to serve people who transit. The dictionary states motel as 'mobile hotel' and accommodation especially for tourists travel by car because the rooms are easily reached from the parking $\operatorname{lot}^{18}$.

The interpretation of motel above also shows that motel customers are tourists who travel by car. It shows their economic condition as rich people. That interpretation also shows the function of motel as accommodation for traveler that is temporary, incidental, and as secondary need. In the social perspective, people who have car are rich.

\section{The Term of Inn}

According to Wikipedia:

\footnotetext{
15 Departemen Pendidikan Nasional, Kamus Besar Bahasa Indonesia Pusat Bahasa. Fourth Edition. Jakarta: PT. Gramedia Pustaka Utama, 2008.

16 Ibid, 508

17 https://id. M.wikipedia.org/wiki/motel

18 Ibid, 930
} 
Inn (Losmen) comes from France language 'logement' means residential, is a kind of commercial accommodation that gives lower price than hotel. ${ }^{19}$ According to Great Dictionary of the Indonesian Language, losmen is an accommodation that rents room without the facility of food ${ }^{20}$.

According to the interpretation above, it shows that losmen is a temporary accommodation, not a residential. Losmen practically is almost the same to hotel but from the lower class. According to the perspective of needs, losmen is a secondary need for the guests on trip.

\section{The Term of Tourist Hut}

Tourist hut is a combination of words hut and tourist. According to Great Dictionary of the Indonesian Language, hut is a small house (usually not in a good condition and temporary), or called dangau. ${ }^{21}$ While the word tourist is everything related to travel for recreation, pleasure trip. ${ }^{22}$ This interpretation also shows that tourist hut has a function as temporary accommodation for the tourists. Tourist hut is a secondary and incidental need. Tourist hut is located near to tourism spot which has high economy value.

\section{The Term of Home-Stay}

The meaning of home-stay according to Great Dictionary of the Indonesian Language is "building as accommodation, office, etc., or a group of houses and residential. ${ }^{23}$ The word home-stay has different meaning, it is not a resident because it is located at tourism area. Therefore, it is interpreted as accommodation. It is used to fulfill secondary, temporary and incidental need.

\section{The Term of Guesthouse}

The Great Dictionary of the Indonesian Language states that guesthouse is a place for resting. ${ }^{24}$ The function of guesthouse according to the interpretation above is as a temporary place to stay.

\footnotetext{
19 https://id.m.wikipedia.org/wiki/losmen

${ }^{20}$ KBBI. Op.cit. p. 842

${ }^{21}$ Ibid. p. 463

22 Ibid. p. 1023

23 Ibid. p. 1563

24 Ibid. p. 1064
} 


\section{The Term of Accommodation}

The term accommodation according to Great Dictionary of the Indonesian Language is a house to stay, or losmen ${ }^{25}$. According to the daily life interpretation, accommodation is a temporary place to stay. The definition of 'hotel' in the Law of Local Taxation and Charges stating 'accommodation, etc.', 'etc.' here is 'a place to stay'.

\section{The Term of Boarding House}

The term boarding house is a place to stay in a certain period of time for daily life. Great Dictionary of the Indonesian Language does not mention the term of boarding house, but there is a term 'rent room' (indekos). The word indekos means:

Stay in other people's house with or without food being charged (by paying every month). Example: my neighbor does not welcome indekos, they only rent the rooms. 26

According to Wikipedia: boarding house is a service in offering a room or place to stay with certain payment in every certain period (monthly in general). The word "kost" is from Dutch word "In de kost" which means 'eat inside', but if the phrase is elaborated, it will mean 'stay and eat' in the owner's house. ${ }^{27}$

Based on the interpretation above, boarding house functions as a place to stay in certain period and not as an accommodation. Accommodation, in daily term, is considered as place to stay over the night, counted per-night or per-day and incidentally because it is not a place for permanent residence.

\section{Interpretation with Law Approach}

In order to explain true meaning of hotel term which is stated in Law of Local Taxation and Charges, Mcleod states that this thing is not enough to know the purpose of Law in making definition of hotel by stating boarding house which has 10 rooms in the term of hotel. Macleod explains that it is also important to know the consideration basic of Law in making definition of hotel.

\footnotetext{
25 Ibid. p. 530

26 Ibid. p. 531

27 Indekost - Wikipedia bahasa Indonesia, ensiklopedia bebas.htm
} 
To know the meaning of Law Designer in making extension of hotel definition in Law of Local Taxation and Charges, it will explain the change of hotel definition started from the making of Law of Local Taxation and Charges in 1997, 2000 and 2009. Here is the definition of hotel as stated by Law No. 18 of 1997 which regulates hotel tax as local taxation from the first time:

Hotel is a special building for people to stay/rest, get service, and or other facilities which is charged, including other united buildings which are managed and owned by the same party, excluding the stores and offices. ${ }^{28}$

The Law No. 34 of 2000 about the change of Republic of Indonesia Law No. 18 of 1997 about Local Taxation and Charges which gives same definition about hotel. This definition clearly states that hotel is not a residence, but a place to stay and rest. To know the reason of Lawmaker in expanding the meaning of hotel by adding meaning of boarding house, we will explain the basic consideration from several Laws which regulate that:

1. Basic Consideration of Law No. 18 in 1997 about Local Taxation and Charges:

... b. that Local taxation and charges are important regional income source to fund the regional government and regional development in establishing the real, dynamic, harmonious, and responsible regional autonomy with consideration in Regional Level II; c. that Law No. 11 Drt. In 1957 about previous General Regulation of Local Charges is no longer appropriate to the recent condition. Therefore, it needs system for renewing Local Taxation and Charges which is simple, fair, effective, and efficient, which can draw people's contribution in funding the regional development..... ${ }^{29}$

2. Basic Consideration of Law No. 34 in 2000 about Changing of Law of Republic of Indonesia No. 18 in 1997 about Local taxation and charges:

........ that the implementation of Regional Autonomy must emphase the principles of democracy, the role of people, distribution and equality, and accountability also pay attention to the regional's potency and diversity ....... ${ }^{30}$

\footnotetext{
${ }^{28}$ Explanation of article 2 paragraph 2 letter a Law No. 18 in 1997 about Local taxation and charges

${ }^{29}$ Law No. 18 in 1997 about Local taxation and charges

${ }^{30}$ Law No. 34 in 2000 About Changing of Law of Republic of Indonesia No. 18 in 1997 about Local taxation and charges
} 
3. Basic Consideration of Law No. 28 in 2009 about Local taxation and charges:

...... that in improving the service for the people and regional's independence, government must expand regional tax object and Local Charges and give discretion in determining the fee; $e$. that regulation of local taxation and charges is done according to the principle of democracy, distribution and equality, people's participation, and accountability with paying attention to the regional potency.... ${ }^{31}$

If we refer to the basic consideration of Law which adds boarding house tax which has more than 10 rooms in the hotel term in order to improve the regional independence, it can be inferred that Lawmaker wants to increase the regional income by expanding the tax object. The tax levied on hotel for boarding house shows the tendency of tax function as budgeter function.

According to the interpretation of 'hotel' which is different in the grammatical meaning and meaning in the Law, in the early time of the making of Law about regulation of tax levied is through Law No. 18 in 1997, it states that:

Hotel is a special building for people who want to stay overnight/rest, get service, and or other facilities which are charged, including other united buildings, managed and owned by the same parties, excluding stores and offices. ${ }^{32}$

The above explanation shows that government in the early time of making regulation for hotel tax refers to the meaning of hotel used in the daily life and in dictionary. Hotel is a place to stay overnight or rest that is temporary and not for residential. Hotel is a temporary transit place and gives services. Law No. 28 in 2009 states that:

Hotel is facility in providing accommodation including other related services which is charged, including motel, losmen, tourist hut, homestay, guesthouse, accommodation, etc, and boarding house with more than 10 rooms. ${ }^{33}$

\footnotetext{
31 Basic Consideration of Law 28 in 2009 about Local Taxation and Charges General Explanation:In the act of this Law, the ability of a regional in funding the outcome is increasing because it can easily adjust its income along with the increase of regional tax basic and discretion in determining the fee. On the other side, by not giving insurance for the people and business is expected to improve people's awareness in fulfilling tax obligatory.

32 Explanation of Article 2 ayah 2 letter a Law No. 18 in 1997 about Local Taxation and Charges.

${ }^{33}$ Article 1 Number 21 Law No. 28 in 2009 about Local Taxation and Charges.
} 
The recent Law explained the same thing towards the meaning of hotel. All of the kinds of accommodation stated in the Law refers to the dictionary and the daily use meaning. Hotel here includes motel, losmen, tourist hut, homestay, guesthouse, accommodation, etc. All kinds of accommodation stated function as place to stay overnight/rest that are temporary and not as resident.

The extension of tax object through the meaning of hotel in Law No. 28 in 2009 including boarding house must be questioned. According to language meaning in daily life and meaning in Indonesian dictionary, boarding house is a residence, not a place to stay overnight. Practically, boarding house mostly used as a residence, for example for the students and employees from out of town who have no house yet.

Government shows that boarding house is a primary need through Regulation of the Minister of Labor No. 13 in 2012 about Component and Implementation of Achievement Stage of a Decent Life Needs. This regulation refers to the component to fulfill the needs of life worth for the labors to determine the minimum wage district (UMK). In the component of residence, there is an item of room rented for one month. The need is need to rent boarding room (because it is calculated per room per month). The explanation of that regulation shows that boarding house is included in the needs of residence which means primary need for the employees.

The definition of boarding houses is definitely different from hotels. The regulation of the boarding houses tax as hotels is too compelling, and the Law makers do not consider that the boarding house is a primary need object for particular community groups. The tax object of hotels in the Law is mentioned on article 32 (1) in the Act of Regional Tax and Regional Retribution (UU PDRD) is:

The tax object of Hotels is services provided by hotels by payments, including for supporting services as hotel facilities which provide the ease and comfort, such as sport and entertainment facilities. ${ }^{34}$

In relation to the abovementioned article, it can be inferred that the tax object of hotels is services provided by hotels. If we find facts in the daily life, boarding houses are services for the living place rent,

34 Article 32 Paragraph 1 Law No. 28 of 2009 about Local Taxation and Charges. 
not the lodging rent, although some luxurious boarding houses offer services like hotels. For the boarding house users such as factory works and college students, they certainly do not expect to get services, yet the rent of living places. To get the definition of 'service', we can refer to the definition in the Indonesian dictionary: Services are regarding with or ways of serving. 35

Practically, it is coincidental that the writer had experienced to live in a boarding house. It was found that boarding houses with the particular low cost, the rent of rooms does not offer services yet it is more for the rent of living places. The term of 'service', has the element of 'serving'. 'Serving' in the Great Dictionary of Indonesian Language means 'helping to provide (manage) what are needed by a person' or it can be defined as 'paying attention'. If there is a 'serving' activity, there are surely 'people who serve' or called as servants.

The services provided by hotels/lodgings are usually in the form of the room comfort, restroom cleanliness, room cleanliness, laundry, and food. For the expensive rent cost boarding houses, there are usually similar services to hotels/ lodgings. However, for the low cost boarding houses and which are provided for factory workers and college students, the services only offer rooms, toilets and kitchens which can be utilized by the tenants to do activities in fulfilling the daily needs.

The hotel services are also regulated by the government in the regulation of Ministry of Tourism and Creative Economy Republic of Indonesia Number Pm.53/Hm.001/Mpek/2013 concerning Standards of Hotel Businesses. Unlike the hotel services having serving standards arranged by the government, boarding houses does not have the standard of services. On the article 1, the Ministry of Tourism regulation explains that: The Service of Hotel Businesses is a process of providing the ease through standard procedures of services.

In accordance with the regulation of Ministry of Tourism, it is clear that services given between hotels and boarding houses are different, and it should become the consistency of the government to use the term and the definition of hotels.

35 Official Dictionary of Indonesian Language, p. 797. Example: 'Selama ini tamu hotel itu tidak mendapat pelayanan yang semestinya'. 
Hotels are one type of accommodations utilizing partly or whole sections for services of lodgings, food and beverages as well as other services for public which are managed commercially. ${ }^{36}$ The definition of hotels show that hotels offers lodging services, not rental services of dwellings. To make it clear whether the rent of lodging rooms and the rent of dwelling rooms is different, it can be seen in the Act of Regional Tax and Regional Retribution (UU PDRD) on the article 32(3) mentioning services excluded in the tax object of hotels:

a. dormitory services managed by the government of the regional government;

b. the rent service of apartments, condominiums, and sort of them;

c. dwelling services in educational centers or religious activities;

d. dwelling services in hospitals, nurse dormitories, retirement houses, orphanages, and other sort of social institutions; and services by bureau of travels or tourism trips held by hotels which are able to utilized by public. ${ }^{37}$

In accordance with the article, it is obvious that the Law has actually defined the differences between lodging services and dwelling services. Nevertheless, in the definition of hotels, the definition of boarding houses is forced to be included in the lodging services.

Considering the principal of justices which is noticed in the Act of Regional Tax and Regional Retribution (UU PDRD), the government should also concern that boarding houses are primary need objects which are surely different from the hotel object as lodging places which are the secondary needs. The government should comprehend about the condition before expanding the meaning of hotels. Despite of having similar serving elements, the boarding house serving elements is as dwelling while the hotels' serving element is as lodging.

\section{The Tax Collection of Boarding Houses based on the Perspective of Islamic Justices}

\footnotetext{
36 Based on the Decree of the Minister of Tourism, Post, and Telecommunication no Km 94/HK103/MPPT 1987

37 Article 32 (3) Local Taxation and Charges Law
} 
Justices are values highly upheld by moral people. Al Quran as the revelation leads the people to act fairly. ${ }^{38}$ All religions teach about the justice. According to Islam, the source of justices is from God, Allah as the fairest. Essentially, it is only Allah having the authority to make the justice (qaiman bil qisth). It is believed that Allah never does tyranny or injustice actions to the people. Surah An Nisa verse 58 describes the justice in terms of equality, which are equality of rights, without differentiating who they are; from where the people who will be given the verdict by people in charge to stand the justice ${ }^{39}$.

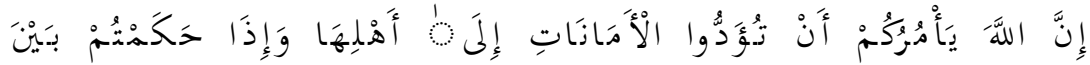

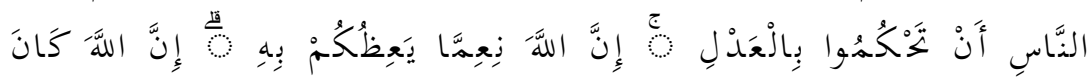

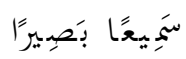

Indeed, Allah commands you to render trusts to whom they are due and when you judge between people to judge with justice. Excellent is that which Allah instructs you. Indeed, Allah is ever Hearing and Seeing.

The tax collection of hotels over boarding houses has to fulfill the social justice. By limiting the number of rooms, it seems that there is still the absence of the justice. For the expensive boarding houses, the boarding house owners are not responsible for paying taxes as long as the number of rooms is not more than 10. This still does not meet the social justice. Such requirement is not suggested by Islam.

Al-Juwayni argues that the purpose of laws consists of three types, primary, secondary, tertiary. The argument of Al-Juwaini is followed by his student, Al-Ghazali. Al-Ghazali explains the aim of laws in relation to welfare. According to Al-Ghazali, welfare is to preserve the religion, the soul, the mind, the generation, and the wealth. The five types of prosperity are in the priority scale and in the different sequence if they are seen from the purposive sides, which are primary, secondary, and tertiary ranks. ${ }^{40}$ The justice of the tax

\footnotetext{
38 Nurfaizal. Paradigma Keadilan Perspektif Al-Qur'an (Tela'ah Riba Dan Jual Beli: Antara Persamaan Dan Perbedaan). An-Nida': Jurnal Pemikiran Islam. Vol.39, No.1 January June of 2014. 29-35

${ }^{39}$ Mahir Amin. Konsep Keadilan Dalam Perspektif Filsafat Hukum Islam. Al Daulah. Vol. 4 No. 2 of 2014. 333

40 Muhammad Hashim Kamali, Shari,,ah Law: An Introduction, (Oxford: Oneworld Publications, 2008), 127
} 
collection toward hotels over boarding houses, considered from the aforementioned description of welfare, is to achieve the well-being of regions to improve the revenue to realize the regional development.

In this case, the government as the institution trusted by the citizen, in making the regulation, should also consider the justice for all groups of society. This is as mandated in the constitution of 1945 that laws made should meet the sense of social justice. It is exceptional for the arrangement of the tax regulation, in the book entitled Wealth of Nation, Adam Smith gives guidelines that to make the fair tax regulation the following four requirements should be fulfilled:41 Equality and equity, Certainty, Convenience of payment, and Economic of collection

The fourth guidelines are called the four maxims. Equality and equity imply that the tax administration must give the same treatment to people with the same condition. Certainty implies that a good tax law can always provide legal certainty to the taxpayer concerning the tax collection procedures, rights and obligations of the taxpayer. In this regard, the tax law should not contain multiple interpretations (ambiguous). If there is a provision on something that may cause multiple interpretations, then an explanation should be given.

Convenience of Payment suggests that taxes should be collected at the right time, when taxpayers have the money. This relates to the taxpayers' capability. Based on the Economic of Collection in tax laws, tax collection should also consider ratio (balance) between the cost of collecting tax with the results of the tax, so negative tax result where the cost incurred for collecting taxes is not expected to be even greater than the amount of tax collected. The expenditure for collecting taxes in this regard should be efficient.

Indonesia is a country that always prioritizes the principle of justice in the life of its nation as can be seen from the foundational philosophical theory of Indonesia that is Pancasila since it influences the nation and state behavior. The word justice is contained in the second principle that is a just and civilized humanity, and is also found in the fifth principle that is social justice for all Indonesian

\footnotetext{
${ }^{41}$ Eikema Hommes in Notoamidjojo. Demi Keadilan dan Kemanusiaan, (Jakarta: BPK
} Gunung Mulia, 1975), 49. 
people. ${ }^{42}$ It shows that Indonesia adheres to the principle of social justice. The commitment of the Indonesian can also be seen in the Preamble of the 1945 Constitution.

The meaning of 'hotel service' and 'boarding house service' has been explained through modern interpretation, and it certainly implied injustice if boarding house is equated with hotel. Based on the type of human needs, the boarding house functions as a residence, and hotel functions as a place of lodging. Moreover, the services provided are also different. Hotel provides lodging services, while boarding houses provides residential rental services. Tax collection of hotels against boarding houses must certainly take it into account.

As stated by Notohamidjojo ${ }^{43}$, social justice demands a decent life for any person in society. Each must be given the opportunity based on menselijke waardigheid (human decency). Development and its implementation should pay attention to justice. The government should concern tax collection over boarding houses, which is a basic need for people as a place to live. It should be treated the same as the collection of Value Added Tax (VAT) that is not imposed on goods that are the basic needs for the community, such as rice, eggs, fruits and vegetables.

The law, as a manifestation of justice, is the most practical tool for achieving a good, just and prosperous life. According to Aristotle, without any tendency of a good ethical social heart towards the citizens, there is no hope for the highest justice in the country despite the wise rulers and good laws. Since the law binds all people, legal justice must be understood as equality in law. The government should pay attention to the right of the citizens to gain happiness and a decent life. According to Aristotle, there are justice with numerical similarity and with proportional equality. Hotel tax collection is categorized into justice with numerical equality (numerical equality creates a principle: "all people are equal before the law"), then the government should definitely give equal treatment to the hotel tax

42 Sila of justice is explained through the elements of the principle of justice in MPR Decree No. II / MPR / 1978 concerning Guidance on the Practice and the Application of Pancasila.

43 Notohamidjojo, O. 1973. Preface, in: W.F. de Graay, Fortman, Rahasia Hukum (translation of O. Notohamidjojo). Jakarta: BPK Gunung Mulia. 
object, for every type of rental service, but not for residential rental service. Hotel tax should include tax objects that are considered as a secondary requirement for the community, but not the tax object of primary needs.

Meanwhile, according to Aristotle, justice with a proportional equality (creating principle: "give each person his/her right"), then the tax collection over boarding house should concern the right of citizens to get a decent life and the tax should not be addressed to the citizens' primary needs. Citizens have the right to fulfill their basic needs in the first place. Afterward, the tax can be levied on them. Although hotel taxes of boarding houses are objective taxes, where tax collection is based on the object (goods or services), the government should still pay attention to the circumstances of the tax subject who consumes goods or services.

Based on the principle of justice according to Aristotle above, the hotels tax collection over boarding houses is already considered unfair. It is more interesting to note that the hotel tax collection is determined based on the circumstances of the taxpayer. It is restricted to the boarding house which has more than 10 rooms. It is still questionable whether the owner of a boarding house who provides less than ten rooms but has luxurious facilities is not taxable, whereas the owner of a boarding house who provides more than 10 rooms but has modest facilities is subject to hotel taxes. The interpretations of some local governments, regarding local regulations, indicate that the restrictions are unclear and considered unfair.

The people who actually need to pay hotel taxes, are tax subjects or hotel taxpayers, have been described in the law of Local Taxation and Charges. It is mentioned in article 1 point 44 and 45 of the law of Local Taxation and Charges that:

- Tax subject is an individual or a Taxable Entity.

- Taxpayer is an individual or an entity, including taxpayers, tax cutters, and tax collectors, who have the right and obligation of taxation in accordance with the provisions of the laws and regulations of local taxation.

Article 33 of the law of Local Taxation and Charges mentions: 
1. The subject of hotel tax is an individual or institution that gives payments to an individual or institution that runs the hotel.44

2. The hotel taxpayer is a person or institution that runs the hotel.

The article explains that the tax subject is the person who may be subject to hotel taxes. So, the tax subject, which is a hotel customer, is actually the one who pays the hotel tax. In boarding house, the one who rents a room in it should pay the hotel tax over boarding house. If the hotel tax collection over boarding houses is based on the condition of the taxpayer, this must be a mistake and is unfair.

According to John Rawls, the principle of inequality in justice is the existence of a regulation concerning a state of difference (socioeconomic). The regulation should be most beneficial to the weakest group of society (at least they can gain the opportunity to reach the prospect of welfare, income and authority). This principle is a combination of two principles, namely the difference principle and the principle of fair equality of opportunity. ${ }^{45}$ Referring to the opinion of Rawls, the regulation of hotel tax collection on boardinghouse with a limited number of rooms based on the taxpayer's condition is unprofitable or does not provide justice for the consumers of boarding houses who are economically incapable (factory workers and students) and stay in a boarding house that has more than 10 rooms. The hotel tax will be levied on them. Meanwhile, the consumers who can afford luxurious boarding house facilities, such as air conditioners, parking lots, cleaning and laundry service, but stay in a boarding house having 10 rooms, will not be levied a hotel tax.

According to Rawls's principle of justice, to realize a justice, the government must make a difference for the socioeconomic conditions of the society who are obligated to pay hotel taxes over boarding houses. The socioeconomic difference is not based on the taxpayer's condition but should be on the tax subject. If the difference is based on the the taxpayer's condition, then the tax collection is not on target and does not provide justice. It is caused by the possibility that tax subjects who are economically capable do not need to pay tax, but the tax subjects who are economically incapable must pay the tax.

\footnotetext{
44 Article 33 (1) of the Law on Local Taxation and Charges

45 Darji Darmidiharjo dan Shidarta. Pokok-Pokok Filsafat Hukum. 1999. Jakarta: PT. Gramedia Pustaka Utama.
} 


\section{Conclusions}

Using the modern interpretation of Ian Mcleod, the real definition of hotel and the services in Local Taxation and Charges Law is acquired. Based on the Official Dictionary of Indonesian Language (KBBI) and daily life language, hotel is as a place to stay. It is different from boarding house which is described as a place to live. Thus, hotel service is the lodging service that has hotel service standard and is usually equipped with other supporting services, such as restaurant service, parking lot, swimming pool, karaoke, and other facilities. The hotel services, as regulated by the Minister of Tourism and Creative Economy of the Republic of Indonesia No. Pm.53/Hm.001/Mpek/2013 concerning Hotel Business Standard, has a special standard that is different from boarding house. Boarding houses do not provide lodging services, but residential rental. In daily life, boarding house is a primary need for people who do not have their own house, while hotel is as a secondary need. It is also mentioned in the Regulation of the Minister of Labor no. 13 of 2012 concerning the Components and Implementation of the Stages of Decent Living Needs Fulfillment. It describes that the renting rooms in a boarding house is a part of the workers' primary needs that should be fulfilled by the employers in form of salary.

According to Aristotle, there is a justice with numerical and proportional equality. The hotel tax collection is categorized into justice with numerical equality (numerical equality creates the principle: "all people are equal before the law"). Therefore, the government should give equal treatment to the hotel tax object, on every type of rental service, but not on the residential rental service. Hotel tax should include tax objects that are considered as a secondary requirement for the community, but not the tax object considered as a primary need. Based on the principle of justice of Aristotle above, the tax collection of hotels over boarding houses already contain unfair elements. Justice with a proportional equality (creating the principle of "giving each person his/her right"), then the tax collection of boarding houses should concern the right of citizens to get a decent life. In other words, tax should not be levied on the primary needs of citizens. They have the right to fulfill their basic needs at the first place. Afterward, tax can be levied on them. The 
provision of tax collection of hotels over boarding houses having more than 10 rooms, as seen from the principle of justice, has not fulfilled the sense of justice.

\section{Bibliography}

Brotodihardjo, R. Santoso. 1991. Pengantar Ilmu Hukum Pajak, Bandung: PT. Eresco.

Bernard L Tanya, Yoan N. Simanjutak, Markus Y. Hage. 2010. Teori Hukum (Strategi Tertib Manusia Lintas Ruang dan Generasi), Yogjakarta: Genta Publishing.

Darji Darmidiharjo dan Shidarta. Pokok-Pokok Filsafat Hukum. 1999. Jakarta: PT. Gramedia Pustaka Utama

Hujbers, Theo. 1984. Filsafat Hukum dalam Lintas Sejarah. (Yogyakarta: Yayasan Kanisius.

Departemen Pendidikan Nasional, 2008. Kamus Besar Bahasa Indonesia Pusat Bahasa. Edisi keempat. Jakarta: PT. Gramedia Pustaka Utama.

Ian McLeod, Legal Method. Macmillan. London.1999.

Jazim Hamidi. 2005. Hermeneutika Hukum. UII Press.

Notohamidjojo, O. 1973. Kata Pengantar, dalam: W.F. de Graay, Fortman, Rahasia Hukum (terjemahan O. Notohamidjojo). Jakarta: BPK Gunung Mulia.

Theo Huijbers. Filsafat Hukum dalam Lintasan Sejarah. Yogyakarta: Yayasan Kanisius, 1984.

Wolfang Friedmann. Legal Theory. London: Stevens \& Son Limited, 1953

Wolfang Friedmann. Teori dan Hukum Telaah Kritis Atas Teori-Teori Hukum (Terj.) Jakarta: PT Raja Grafindo Persada, 2001.

Peter Mahmud Marzuki, 2005, Penelitian Hukum, Prenada Media: Surabaya.

\section{Articles}

A Williantino. Peran Dinas Pendapatan Daerah Kabupaten Banyuwangi Dalam Optimalisasi Penerimaan Dari Sektor Pajak Rumah Kos Lebih Dari 10 Kamar. Jurnal Mahasiswa Fakultas Hukum, Februari 2015

Anjani Dwi Swastika, Devi Pusposari. Persepsi Pemilik Rumah Kos Terhadap Peraturan Daerah Kota Malang Nomor 16 Tahun 2010 
Tentang Pajak Daerah. Jurnal Ilmiah Mahasiswa FEB. Vol 2, No 2 (2013)

Ew. Mewah. Efektivitas Dan Kontribusi Penerimaan Pajak Hotel Dan Restoran Terhadap PAD Kota Manado. Jurnal Riset Ekonomi, Manajemen, Bisnis. Desember 2013.

Lisa Hendra Jaya, Retnaningtyas Widuri. Analisis Potensi Pajak Hotel Terhadap Realisasi Penerimaan Pajak Hotel Berbintang Di Surabaya. Tax And Accounting Review. Vol. 1 No. 1 (2013)

Mahir Amin. Konsep Keadilan Dalam Perspektif Filsafat Hukum Islam. Al Daulah. Vol. 4 No. 2 Tahun 2014, hlm. 322-343.

Niken Wulandari Analisis Kepatuhan Wajib Pajak Terhadap Peraturan Daerah Kota Malang Nomor 16 Tahun 2010 Kategori Pajak Rumah Kos. Jurnal Mahasiswa Perpajakan. Vol 7, No 1 (2015)

Nurfaizal. Paradigma Keadilan Perspektif Al-Qur'an (Tela'ah Riba Dan Jual Beli: Antara Persamaan Dan Perbedaan). An-Nida': Jurnal Pemikiran Islam. Vol.39,No.1 Januari - Juni 2014. 29-35

\section{Internet}

NTT Online.kupang.Pajak Kos-kosan Tidak Lagi Berdasarkan Jumlah Kamar.htm. 5 Maret 2015

Koran Tempo. Rumah Kos Dikenakan Pajak. 20 November 2010.

\section{Peraturan Perundang-Undangan}

Undang-Undang No. 6 Tahun 1983 tentang Ketentuan Umum dan Tata Cara Perpajakan

Undang-Undang No. 7 Tahun 1983 tentang Pajak Penghasilan

Undang-Undang No. 7 Tahun 1991 tentang Perubahan Atas UndangUndang No.7 Tahun 1983 tentang Pajak Penghasilan.

Undang-Undang No 9 Tahun 1994 tentang Perubahan UndangUndang No. 6 Tahun 1983 tentang Ketentuan Umum dan Tata Cara Perpajakan.

Undang-Undang No. 11 Tahun 1994 tentang Perubahan atas UndangUndang No. 8 Tahun 1983 tentang Pajak Pertambahan Nilai Barang dan Jasa dan Pajak Penjualan atas Barang Mewah.

Undang-Undang No. 18 Tahun 1997 tentang Pajak Daerah dan Reribusi Daerah

Undang-Undang No. 28 Tahun 2009 tentang Pajak Daerah dan Reribusi Daerah 